Keywords: $M C U, A R P, I S D P$

Retention: Permanent

\title{
Solvent Hold Tank Sample Results for MCU-11-314, MCU-11-315, MCU-11-316, MCU-11-317, MCU-11-318 and MCU-11-319
}

T. B. Peters

A. L. Washington

F. F. Fondeur

S. D. Fink

June 2011

Savannah River National Laboratory Savannah River Nuclear Solutions

Aiken, SC 29808

Prepared for the U.S. Department of Energy under

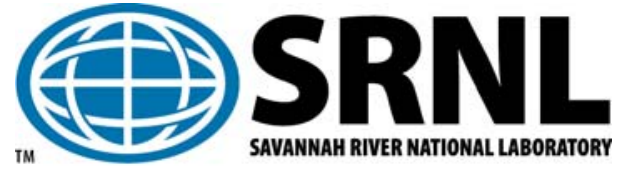
contract number DE-AC09-08SR22470. 
SRNL-STI-2011-00301

Revision 0

\section{DISCLAIMER}

This work was prepared under an agreement with and funded by the U.S. Government. Neither the U.S. Government or its employees, nor any of its contractors, subcontractors or their employees, makes any express or implied:

1. warranty or assumes any legal liability for the accuracy, completeness, or for the use or results of such use of any information, product, or process disclosed; or

2. representation that such use or results of such use would not infringe privately owned rights; or

3. endorsement or recommendation of any specifically identified commercial product, process, or service.

Any views and opinions of authors expressed in this work do not necessarily state or reflect those of the United States Government, or its contractors, or subcontractors.

\section{Printed in the United States of America}

Prepared for

U.S. Department of Energy 


\section{REVIEWS AND APPROVALS}

\section{AUTHORS:}

T. B. Peters, Author, SRNL/SASP

Date

F. F. Fondeur, Co-author, SRNL/SASP

Date

TECHNICAL REVIEW:

C. A. Nash, Technical Reviewer, SRNL/ACP

Date

APPROVAL:

S. D. Fink, SRNL/SASP, Manager

Date

S. L. Marra, SRNL/E\&CPT Research Programs, Manager

Date

D. J. Martin, H Tank Farm Process Engineering

Date 


\section{EXECUTIVE SUMMARY}

Savannah River National Laboratory (SRNL) analyzed solvent samples from Modular Caustic-Side Solvent Extraction Unit (MCU) in support of continuing operations. A quarterly analysis of the solvent is required to maintain solvent composition within specifications. Analytical results of the analyses of Solvent Hold Tank (SHT) samples MCU-11-314, MCU-11-315, MCU-11-316, MCU-11-317, MCU-11-318 and MCU-11-319 are reported. The results show that the solvent at MCU does not require an Isopar ${ }^{\circledR} \mathrm{L}$ addition, but it will require addition of trioctylamine. Cesium mass transfer testing with the solvent matches expected extraction behavior but shows a slightly lower stripping efficiency than seen in the original process demonstration for Macrobatch 3.

The entrained aqueous solution indicates the scrub wash is significantly out of specification. As a result, the facility replaced the scrub wash. 


\title{
LIST OF ABBREVIATIONS
}

\author{
DF - decontamination factor \\ ESS - Extraction, Scrub, Strip \\ FTIR - Fourier transform infra-red spectroscopy \\ HPLC - High Performance Liquid Chromatography \\ ISDP - Integrated Salt Disposition Project \\ SHT - Solvent Hold Tank \\ SRNL - Savannah River National Laboratory \\ SVOA - Semi Volatile Organic Analysis \\ TOA - trioctylamine
}




\subsection{Introduction}

Solvent Hold Tank (SHT) samples are sent to Savannah River National Laboratory (SRNL) to examine solvent composition changes over time. ${ }^{1}$ On April 12, 2011, Operations personnel delivered six samples from the SHT (MCU-11-314 through -319) for analysis. These samples are intended to verify that the solvent is within the specified composition range. The results from the analyses are presented in this document.

These samples were pulled shortly after the previous solvent adjustment on April 7, 2011. At that time, the previous quarterly solvent report ${ }^{2}$ indicated the need to add trioctylamine (TOA). SRNL supplied a calculated amount of TOA that once added to the SHT, would raise the TOA concentration back to nominal (1020 mg/L) levels.

Since the facility has observed a decline in cesium decontamination factor (DF) recently, the customer also requested that SRNL examine the cesium mass transfer behavior for the solvent in a standard extraction, scrub, and strip test.

\subsection{Experimental Procedure}

Samples were received in p-nut vials containing $~ 10 \mathrm{~mL}$ each. Once taken into the Shielded Cells, the samples were combined. Samples were removed for analysis by density, semi-volatile organic analysis (SVOA), high performance liquid chromatography (HPLC), and Fourier-Transform Infra-Red spectroscopy (FTIR).

Details for the work are contained in a controlled laboratory notebook. ${ }^{3}$

\subsection{Results and Discussion}

There was liquid in all six of the p-nut vials. One vial was mostly aqueous (MCU-11-316), while one other vial was mostly organic, with $\sim 1 \mathrm{~mL}$ of aqueous material also present (MCU-11-315). The samples were combined, and the aqueous phase transferred into a new bottle. A pH measurement of the aqueous material gave a result of 7. In principle, any aqueous phase carryover in the solvent samples should be from the caustic wash. The caustic wash starts as $0.01 \mathrm{M} \mathrm{NaOH}$, and so aqueous carryover should remain close to $\mathrm{pH} 12$. Based in part on this finding and the low cesium removal in the facility, the scrub wash was replaced. As of this writing SRNL is also analyzing the aqueous phase for sodium and nitrate content. A density measurement of the organic phase gave a result of $0.8434 \mathrm{~g} / \mathrm{mL}$.

Using the density as a starting point, we know that the Isopar ${ }^{\circledR} \mathrm{L}$ should be higher than nominal and the other components should be lower than nominal. The Isopar ${ }^{\circledR} \mathrm{L}$ 
analyses from the various measurements - see Table 1 - are in agreement, as well as 3 of 4 of the Modifier measurements. The SVOA Modifier analysis is high, but marginally within its analytical uncertainty of the other measurements.

The extractant analysis is also higher than expected - given the other results, the extractant concentration should be under nominal values. Using the measured density and the Isopar ${ }^{\circledR} \mathrm{L}$ and Modifier concentrations from the FTIR results, we calculate an extractant concentration of $7860 \mathrm{mg} / \mathrm{L}$. This value is well within the analytical uncertainty of the reported HPLC value.

When compared to the target density of $0.845 \mathrm{~g} / \mathrm{mL}$, there is no need to add an Isopar ${ }^{\circledR} \mathrm{L}$ trim. However, it is advisable to add sufficient TOA to return the solvent composition to within specifications as that component has declined to about $57 \%$ the concentration since the last analysis. This is an unexpected result given that a solvent trim was performed less than a week before this set of samples was pulled. SRNL is investigating the possible reasons for this low result.

The initial trioctylamine results were 540 and $540 \mathrm{mg} / \mathrm{L}$ (duplicate analyses). Due to this unexpectedly low result, SRNL analyzed the sample in duplicate again. The new results were 620 and $630 \mathrm{mg} / \mathrm{L}$. The average of all four results is reported in Table 1.

SRNL also analyzed the solvent composite sample for ${ }^{137}$ Cs content. The result is listed in Table 2. SRNL does not normally analyze SHT samples for ${ }^{137} \mathrm{Cs}$ content. We have only a single appropriate result from 2008; MCU-08-166/167. At that time, the SHT gave a ${ }^{137} \mathrm{Cs}$ measurement of $1.17 \mathrm{E}+07 \mathrm{dpm} / \mathrm{mL}$. ${ }^{4}$ The different operating conditions for that sample and the current ones make a detailed comparison difficult, but we can note that the current SHT sample does not appear to indicate stripping problems.

Upon a customer request, SRNL used $30 \mathrm{~mL}$ of the SHT sample to perform an Extraction-Scrub-Strip (ESS) test. For the aqueous phase, we used actual Tank $49 \mathrm{H}$ sample (a composite of HTF-49-11-9, HTF-49-11-11, HTF-49-11-12, HTF-49-11-15, HTF-49-11-16, HTF-49-11-17, HTF-49-11-18, HTF-49-11-19, HTF-49-11-20, HTF-49-11-21, HTF-49-11-22).

Table 3 shows the results from the ESS Test, corrected to the normal process operating temperatures (i.e., $23{ }^{\circ} \mathrm{C}$ for extraction and $33{ }^{\circ} \mathrm{C}$ for scrubbing and stripping). As a comparison, the results from the previous macrobatch qualification ESS test (using the same solvent) in 2010 are displayed, ${ }^{6}$ as well as the predicted value for the extraction \#1 step. $^{5}$ 
Table 1. Sample Results for MCU-11-314/315/316/317/318/319 Composite

\begin{tabular}{|c|c|c|c|c|c|}
\hline Analysis & Method & LIMS \# & $\begin{array}{l}\text { Result } \\
(\mathrm{mg} / \mathrm{L})^{\#}\end{array}$ & $\begin{array}{c}\text { Nominal }^{*} \\
\text { Result } \\
(\mathrm{mg} / \mathrm{L})\end{array}$ & $\begin{array}{l}\text { \% of (Result } \div \\
\text { Nominal Result) }\end{array}$ \\
\hline Isopar $^{\circledR} \mathrm{L}$ & SVOA & 300285984 & 620,000 & 589,000 & $105 \%$ \\
\hline Isopar $^{\circledR} \mathrm{L}$ & FTIR & NA & 601,000 & 589,000 & $102 \%$ \\
\hline Isopar ${ }^{\circledR} \mathrm{L}$ & Density $^{\Upsilon}$ & NA & 601,000 & 589,000 & $102 \%$ \\
\hline average & all & NA & 607,000 & 589,000 & $103 \%$ \\
\hline Modifier & SVOA & 300285984 & 280,000 & 254,000 & $110 \%$ \\
\hline Modifier & HPLC & 300285984 & 231,000 & 254,000 & $90.9 \%$ \\
\hline Modifier & FTIR & NA & 234,000 & 254,000 & $92.1 \%$ \\
\hline Modifier & Density $^{\Upsilon}$ & NA & 234,000 & 254,000 & $92.1 \%$ \\
\hline average & all & NA & 245,000 & 254,000 & $96.5 \%$ \\
\hline trioctylamine & SVOA & 300285984 & 583 & 1,020 & $57.2 \%$ \\
\hline Extractant & HPLC & 300285984 & 8600 & 8,000 & $108 \%$ \\
\hline Density & $\begin{array}{c}\text { Direct } \\
\text { measurement }\end{array}$ & NA & 0.8434 & $\begin{array}{l}0.852 \\
\mathrm{~g} / \mathrm{mL}\end{array}$ & $99.0 \%$ \\
\hline
\end{tabular}

" Analytical uncertainty is $10 \%$ for SVOA and $10 \%$ for HPLC. FTIR analytical uncertainty is $15 \%$ for Isopar ${ }^{\circledR} \mathrm{L}$ and $10 \%$ for Modifier. Density results from the average of replicate volumetric trials typically have a percentage standard deviation of $<1 \%$ between each value and the average.

${ }^{*}$ Nominal value is the expected value for freshly prepared solvent. ${ }^{6}$

$\mathrm{NA}=$ not applicable

Table 2. ${ }^{137}$ Cs Activity in the SHT Sample

\begin{tabular}{|c|c|}
\hline Analyte & Result (dpm/mL) \\
\hline${ }^{137} \mathrm{Cs}$ & $7.99 \mathrm{E}+05(5.00 \%)$ \\
\hline
\end{tabular}

\footnotetext{
${ }^{\Upsilon}$ We can estimate the Isopar ${ }^{\circledR} \mathrm{L}$ and Modifier concentrations by knowing the densities of the individual components and using the Microsoft Excel goal seek function to assess a range of Isopar ${ }^{\circledR}$ L, Modifier and TOA compositions to arrive at the measured density.
} 
Table 3. Cesium Distribution Values for the ESS Test

\begin{tabular}{|c|c|c|c|c|c|c|}
\hline Material & Extraction & Scrub \#1 & Scrub \#2 & Strip \#1 & Strip \#2 & Strip \#3 \\
\hline Acceptable Range & $>8$ & $>0.6,<2$ & $>0.6,<2$ & $<0.2$ & $<0.16$ & $<0.16$ \\
\hline $\begin{array}{c}\text { S2-D1-YES BOB-T- } \\
\text { WI, Macrobatch 3 }\end{array}$ & 16.4 & 1.81 & 2.58 & 0.122 & 0.0371 & 0.0360 \\
\hline $\begin{array}{c}\text { MCU Facility Solvent } \\
\text { (current test) }\end{array}$ & 17.4 & 10.8 & 1.18 & 0.0623 & 0.0736 & 0.0757 \\
\hline Predicted & 16.0 & & & & & \\
\hline
\end{tabular}

The current test shows unusual Scrub \#1 results, but otherwise typical behavior for this solvent. The atypical Scrub \#1 value is probably tied to the fact that the $\mathrm{pH}$ measurement of Scrub\#1 aqueous phase, after the contact period was measured to be 14 (as opposed to the 2.5 that it should be). Scrub \#1 is the step with the largest $\mathrm{pH}$ swing (strong caustic aqueous phase to dilute acid phase) and is subject to interference if even a small amount of caustic is entrained.

The extraction value, along with the ${ }^{137} \mathrm{Cs}$ value from Table 2 indicates that the solvent did not arrive in a preferentially loaded state. Other than Scrub \#1, each step is within acceptable parameters. However, the stripping behavior is these limited tests are slightly poorer than in the original process demonstration for Macrobatch 3. SRNL recommended that Engineering model the expected facility performance shift using these results to determine is Cs reflux could be occurring. Engineering completed calculations using the ESS test results. Compared to the Macrobatch 3 ESS qualification test, the current ESS test results run predict a $\sim 50 \%$ decline in the DF.

\subsection{Conclusions}

Unlike the previous solvent sample results, ${ }^{2}$ these analyses indicate that the solvent does not require minor Isopar ${ }^{\circledR}$ L trimming at this time. However, addition of TOA is warranted. These findings indicate that the new protocols for solvent monitoring and control are yielding favorable results. Nevertheless, the deviation in the TOA concentration since the last analysis indicates continued periodic (i.e., quarterly) monitoring is recommended.

The ${ }^{137}$ Cs mass transfer results from the solvent sample testing show possible evidence of slightly reduced stripping efficiency. An evaluation (using a model) of expected system performance for MCU using the measured distribution values predicts a 50\% decline in DFs given the ESS test results. The customer should consider pulling a SHT sample for reanalysis. 
SRNL-STI-2011-00301

Revision 0

\subsection{References}

${ }^{1}$ W. M. Matthews, HLW-CRF-10006, Rev. 0, May 18, 2010.

${ }^{2}$ T. B. Peters, F. F. Fondeur, and S. D. Fink, "Solvent Hold Tank Sample Results for MCU-11-56 and MCU-11-57”, SRNL-STI-2011-00073, February, 2011.

${ }^{3}$ T. B. Peters, "ISDP3”, SRNL-NB-2009-00153, October 28, 2009.

${ }^{4}$ T. B. Peters, F. F. Fondeur, S. L. Crump, T. L. White, S. D. Fink, "SHT Sample Results for MCU-08-166, -167, -252, -253”, SRNL-L3100-2008-00120, Rev.0, November 18, 2008.

${ }^{5}$ L. H. Delmau, D. A. Bostick, T. J. Haverlock, B. A. Moyer, "Caustic-Side Solvent Extraction:

Extended Equilibrium Modeling of Cesium and Potassium Distribution Behavior”, ORNL/TM-2002/116, May 2002.

${ }^{6}$ L.H. Delmau, J. F. Birdwell Jr., P. V. Bonnesen, L. J. Foote, T. J. Haverlock, L. N. Klatt, D. D. Lee, R. A. Leonard, T. G. Levitskaia, M. P. Maskarinec, B. A. Moyer, F. V. Sloop Jr., B. A. Tomkins, "Caustic-Side Solvent Extraction: Chemical and Physical Properties of the Optimized Solvent”, October 2002, ORNL/TM-2002/190

${ }^{7}$ T. B. Peters, S. D. Fink, "Results from Monosodium Titanate (MST) and Extraction-Scrub-Strip (ESS) Testing of ISDP Macrobatch 3 Blend”, SRNL-STI-2010-00290, May 2010. 


\section{Distribution:}
A. B. Barnes, 999-W
D. A. Crowley, 773-43A
S. D. Fink, 773-A
B. J. Giddings, 786-5A
C. C. Herman, 999-W
S. L. Marra, 773-A
F. M. Pennebaker, 773-42A
E. J. Freed, 704-56H
D. J. Martin, 241-152H
M. W. Geeting, 241-152H
S. P. McLeskey, 241-152H
B. A. Gifford, 704-56H
S. A. Thomas, 703-46A
T. B. Peters, 773-42A
C. A. Nash, 773-42A
M. R. Poirier, 773-42A
F. F. Fondeur, 773-A
P. R. Jackson, 703-46A 